\title{
JEDNOSTRANI RASKID KUPOPRODAJNOG UGOVORA POSLIJE DOSPIJEĆA OBVEZA STRANA PREMA KONVENCIJI UN O MEĐUNARODNOJ PRODAJI ROBE
}

Prof. dr. sc. Zvonimir Slakoper*

Josip Dešić, mag. iur.**

\author{
UDK: 339.542:347.451 \\ https://doi.org/10.30925/zpfsr.41.1.9 \\ Ur.: 15. siječnja 2020. \\ Pr.: 2. travnja 2020. \\ Prethodno priopćenje
}

\begin{abstract}
Sažetak
U radu se daje prikaz jednostranoga raskida kupoprodajnog ugovora poslije dospijeća obveza strana prema Konvenciji UN-a o međunarodnoj prodaji robe (Bečka konvencija). Bečka konvencija danas je na snazi u 93 države iz svih pravnih tradicija $i$ razina gospodarskog razvoja koje zajedno predstavljaju preko dvije trećine globalnog gospodarstva. Ugovori o prekograničnoj prodaji robe okosnica su međunarodne trgovine i stoga se Bečka konvencija smatra jednom od temeljnih konvencija međunarodnoga trgovačkog prava. Kako bi bila što prihvatlivija različitim pravnim poredcima, Bečka konvencija u mnogome je odstupila od rješenja nacionalnih prava $i$ pravnih krugova $i$ stvorila autonomne pojmove i rješenja. Posebna kreativna rješenja predvidjela je za raskid ugovora. U radu se analizira raskid zbog bitne povrede ugovora, koncepta kakav ne predviđa niti jedan građanski i trgovački zakon, zatim raskid zbog neispunjenja u dodatnom roku, raskid zbog neuskladenosti te raskid zbog prava ili potraživanja treće osobe. Posebna pažnja posvećuje se i potpunom $i$ djelomičnom raskidu te raskidu ugovora kod sukcesivnih isporuka. Zaključno se analizira gubitak prava na raskid.
\end{abstract}

Ključne riječi: jednostrani raskid ugovora o kupoprodaji; Konvencija UN o međunarodnoj prodaji robe; bitna povreda ugovora.

\section{UVOD}

Izraz „raskid ugovora“ podrazumijeva prestanak valjanog ugovora prije no što su u cijelosti ispunjene sve primarne, odnosno namjeravane, obveze ugovornih strana, ${ }^{1}$ pa mogućnost raskida prestaje tek kada obje strane sve primarne obveze

* Dr. sc. Zvonimir Slakoper, redoviti profesor u trajnom zvanju, Sveučilište u Rijeci, Pravni fakultet; zvonimir.slakoper@pravri.hr.

** Josip Dešić, mag. iur., asistent, Sveučilište u Rijeci, Pravni fakultet; jdesic@pravri.hr.

1 Tako Zvonimir Slakoper i Vilim Gorenc, Obvezno pravo - opći dio (Zagreb: Novi informator, 2009.), 572. Slično i Petar Klarić i Martin Vedriš, Građansko pravo (Zagreb: Narodne novine, 2006.), 69 . 
ispune u cijelosti. Izraz ,jednostrani raskid ugovora“ podrazumijeva raskid ugovora izjavom volje jedne ugovorne strane.

Konvenciji UN o međunarodnoj prodaji robe (Bečkoj konvenciji), ${ }^{2}$ čijom je stranom ugovornicom Hrvatska postala notificiranjem sukcesije u članstvo, do pisanja ovoga rada pristupile su 93 države, među kojima su i države u kojima mjesto poslovanja imaju trgovačka društva s kojima trgovačka društva s mjestom poslovanja u Hrvatskoj sklapaju najviše kupoprodajnih ugovora. Stoga se Konvencija primjenjuje na većinu kupoprodajnih ugovora s međunarodnim obilježjem, koje sklapaju trgovačka društva s mjestom poslovanja u Hrvatskoj. Iz toga proizlazi važnost prikaza i poznavanja rješenja Konvencije.

Ova važnost proizlazi poglavito iz okolnosti što je Konvencija, u nastojanju da bude prihvatljiva različitim pravnim poredcima, u mnogome odstupila od rješenja nacionalnih prava i pravnih krugova i stvorila autonomne pojmove i rješenja, koja jezično mogu podsjećati na rješenja pojedinih pravnih poredaka, ali trebaju biti shvaćena, tumačena i primijenjena neovisno o njima.

Tako Konvencija ne poznaje ni pojam roka kao bitnog sastojka ugovora, niti raskid ugovora kao neposrednu posljedicu neispunjenja obveze do isteka tog roka, nego samo raskid jednostranim očitovanjem volje ugovorne strane. Također ne razlikuje ispunjenje obveze drugim predmetom (aliud) umjesto ugovorenog od ispunjenja koje Zakon o obveznim odnosima ${ }^{3}$ opisuje kao ispunjenje s materijalnim nedostatcima, a ne rabi ni izraz ,pravni nedostatci“. Umjesto toga, ona rabi izraz „povreda ugovora“, kojim opisuje i obuhvaća svako odstupanje ispunjenja bilo koje obveze ugovorne strane, glede svih i svakog pojedinog od elemenata ispunjenja, od onog što proizlazi iz ugovora, pa povreda ugovora nastaje čim nastane takvo odstupanje. ${ }^{4}$ Među odredbama o obvezama prodavatelja nalazi se odredba prema kojoj je ,prodavalac je dužan isporučiti robu u količini, kvaliteti i vrsti kako je to predviđeno ugovorom te pakiranu ili zaštićenu na način predviđen ugovorom", 5 što znači da je identitet robe izjednačen s njenim svojstvima, a nepostojanje identiteta robe podvrgnuto je istom pravnom režimu kojem je podvrgnuto nepostojanje potrebnih svojstava. Nadalje je prodavatelj dužan isporučiti robu slobodnu „od prava ili potraživanja treće osobe“, 6 a ne robu bez pravnih nedostataka.

Konvencija je strukturirana tako da u čl. 30.-52. uređuje obveze prodavatelja, uključujući i sredstva kojima raspolaže kupac ako prodavatelj povrijedi ugovor, a u čl.

2 Službeni list SFRJ, Međunarodni ugovori, br. 10/84. i Narodne novine, Međunarodni ugovori, br. 15/98. (dalje u tekstu: Konvencija).

3 Narodne novine, br. 35/05., 41/08., 78/15. i 29/18. (dalje u tekstu: ZOO).

4 To proizlazi iz naslova Glave III Odsjeka III o sredstvima „kojima raspolaže prodavalac ako kupac povrijedi ugovor“ i Glave II Odsjeka III o sredstvima „kojima raspolaže kupac ako prodavalac povrijedi ugovor" u vezi s prvim i temeljnim odredbama o sredstvima jedne strane kad druga strana povrijedi ugovor, koje počinju riječima „,ako kupac ne izvrši bilo koju od svojih obveza“ (Početak uvodne rečenice čl. 61. (1) Konvencije.), odnosno ,ako prodavalac ne izvrši bilo koju svoju obvezu“ (Početak uvodne rečenice čl. 45. (1) Konvencije.). Već ovdje se može uočiti kako službeni prijevod Konvencije na hrvatski jezik odstupa od današnjeg jezičnog standarda, što se u tekstu rada može ispraviti, ali ne i pri citiranju službenog teksta.

5 Čl. 35. st. 1. Konvencije.

6 Čl. 41. Konvencije, prva rečenica. 
53.-65. obveze kupca, uključujući i sredstva kojima raspolaže prodavatelj ako kupac povrijedi ugovor. Među tim se odredbama nalaze i odredbe o jednostranom kupčevom i prodavateljevom raskidu ugovora. Prve od tih odredbi sadržajno su istovjetne, osim što su uloge strana zamijenjene i prema njima i kupac i prodavatelj mogu izjaviti da raskidaju ugovor ako neispunjenje bilo koje obveze, koju druga strana ima na temelju ugovora ili ove konvencije, predstavlja bitnu povredu ugovora. ${ }^{7}$

Sadržajno su bitno istovjetne i druge od tih odredbi. Osim kad neispunjenje bilo koje obveze druge strane predstavlja bitnu povredu ugovora, i kupac i prodavatelj mogu jednostrano raskinuti ugovor u slučaju neispunjenja obveza druge strane $u$ dodatnom roku.

Nakon toga će se izložiti pitanje jednostranog raskida ugovora zbog neusklađenosti, i prava i zahtjeva trećih, zatim posebna pravila o jednostranom raskidu ugovora kod uzastopnih isporuka, a na kraju i pravila o gubitku prava na raskid ugovora. Kako tekst ne bi bio previše opsežan, pravila o učincima raskida ugovora neće se prikazivati.

\section{RASKID ZBOG BITNE POVREDE UGOVORA}

Kao što je već navedeno, pravilo o jednostranom raskidu ugovora zbog bitne povrede ugovora koju je počinila druga strana, nije sadržano u jednoj, nego u dvije odredbe. Njihov je sadržaj istovjetan, osim utoliko što su uloge strana zamijenjene, pa se sažeto može reći da jedna strana može izjaviti da raskida ugovor ako neispunjenje bilo koje obveze koju druga strana ima na temelju ugovora ili Konvencije predstavlja bitnu povredu ugovora. ${ }^{8}$

Bitna povreda ugovora opisana je u čl. 25. Konvencije i prema toj odredbi povreda ugovora je bitna ,ako se njome uzrokuje takva šteta drugoj strani da je bitno lišava onog što je opravdano očekivala od ugovora, osim ako takvu posljedicu nije predvidjela strana koja čini povredu niti bi je predvidjela razumna osoba istih svojstava u istim okolnostima“. Proizlazi da bi prouzročenje štete ugovornoj strani bila pretpostavka postojanja bitne povrede ugovora, jer se prema citiranom tekstu bitnom povredom drugoj strani „uzrokuje... šteta“.

To nije točno i nastanak štete, smanjenje imovine, sprječavanje njenog povećanja ili povreda prava osobnosti, nije pretpostavka postojanja bitne povrede ugovora. Naime, prema engleskom izvorniku takva povreda drugoj strani uzrokuje detriment, ${ }^{9}$

7 Prema čl. 49. (1) (a) „kupac može izjaviti da raskida ugovor... ako je neizvršenje bilo koje obveze koju prodavalac ima na temelju ugovora ili ove konvencije bitna povreda ugovora", a prema čl. 64. (1) (a) ,prodavalac može izjaviti da raskida ugovor... ako neizvršenje bilo koje obveze koju kupac ima na temelju ugovora ili ove konvencije predstavlja bitnu povredu ugovora".

8 Čl. 49. (1) (a) i čl. 64. (1) (a) Konvencije v. u bilj 35.

9 Čl. 25. Konvencije u engleskom izvorniku glasi „A breach of contract committed by one of the parties is fundamental if it results in such detriment to the other party as substantially to deprive him of what he is entitled to expect under the contract, unless the party in breach did not foresee and a reasonable person of the same kind in the same circumstances would not have foreseen such a result". 
prema francuskom prejudice, a prema njemačkom prijevodu Nachteil. Izraz detriment može se shvatiti kao nedostatak, nesposobnost, ${ }^{10}$ oštećenje ili gubitak ${ }^{11} \mathrm{u}$ širem smislu. Usporedivo s tim, Nachteil se može shvatiti kao gubitak ili oduzimanje, a prema literaturi detriment upućuje na povredu, štetu i gubitak u širokom i neodređenom smislu i uz napomenu kako nije nužno da šteta bude stvarna, odnosno da položaj bude faktički pogoršan, nego da bude pogoršan u pravnom smislu. ${ }^{12}$ Osim toga, u literaturi se uočava da je u vrijeme potpisivanja Konvencije pojam detriment predstavljao novi pojam koji nije bilo lako pronaći u međunarodnim pravnim dokumentima, niti je predstavljao standard u common lawu, dok su pojam prejudice iz francuskog izvornika i odgovarajući pojmovi iz španjolskog i ruskog izvornika u tim pravnim poredcima redovito podrazumijevali povredu, štetu, gubitak, ali u širokom i neodređenom smislu.

Stoga, po mišljenju autora, prevođenje izraza detriment u čl. 25. Konvencije moglo se izostaviti bez gubitka smisla te odredbe, te se ona mogla prevesti jasnije i tako da se bolje uoči njen smisao, primjerice riječima da je povreda ugovora bitna „,ako drugoj strani bitno oduzme ono što je ona ovlaštena očekivati prema ugovoru“ ili ,ako je zbog nje drugoj strani bitno oduzeto ono što je ona ovlaštena očekivati prema ugovoru“. Riječ je o uzročnoj vezi između povrede ugovora i bitnog oduzimanja drugoj strani onog što je ona ovlaštena očekivati prema ugovoru.

Povreda ugovora koja drugoj strani bitno oduzima ono što je ona imala pravo očekivati od ugovora lijepo je na općeniti način opisana u sudskoj praksi. Navodi se da je ,povreda ugovora bitna kad je svrha ugovora ugrožena toliko ozbiljno da je, zbog povrede ugovora, za ugovornu stranu prestao postojati interes za ispunjenje“", ${ }^{3}$ da je za postojanje bitne povrede potrebno da se ona „odnosi na bitan sadržaj ugovora, robu ili plaćanje cijene i da mora voditi k ozbiljnim posljedicama na ekonomski cilj“"14 i da je ispunjenje povrijeđene ugovorne odredbe ,toliko bitno da bi (ugovorna strana - op. a.) odbila ugovor da je znala za takvu buduću povredu“. ${ }^{15}$ Iako se spominje ekonomski cilj i posljedice na ekonomski cilj, nužno je naglasiti da se u prvom redu ne radi o opsegu pretrpljenoga gubitka, nego o važnosti interesa za savjesnu ugovornu stranu. ${ }^{16}$ Stoga će i opseg pretrpljene štete biti važan čimbenik pri ocjeni o tome je li povreda ugovora bitna, ali nastanak štete sam po sebi nije pretpostavka da bi povreda ugovora bila bitna. ${ }^{17}$

Osim ovih općenitih navoda o osobinama povrede ugovora koje su nužne da bi

10 Mairé Weir Kay, Webster's collegiate thesaurus (Springfield, Mass: Merriam-Webster., 1976.), 224.

11 Bryan A. Garner, ur., Black's Law dictionary (St. Paul, MN: West, 2004.), 481. Slično Will $\mathrm{u}$ : Cesare Massimo Bianca i Michael Joachim Bonell, eds., Commentary on the International Sales Law: The 1980 Vienna Sales Convention (Milan: Giuffrè, 1987.), 468 i 210.

12 Will u: Bianca i Bonell, Commentary on the International Sales Law, 210.

13 Odluka Oberlandesgericht Frankfurt od 17. rujna 1991., odluka br. 28., www.cisg.law.pace. edu.

14 Odluka švicarskog Bundesgericht od 15. rujna 2000, odluka br. 770., www.cisg.law.pace.edu.

15 Odluka švicarskog Bundesgericht od 15. rujna 2000, odluka br. 770., www.cisg.law.pace.edu.

16 Tako odluka Vrhovnog suda Poljske, br. 1790 od 11. svibnja 2007., cisg-online.ch švicarskog Bundesgericht od 23. rujna 2013., odluka br. 2560, cisg-online.ch i njemačkog Bundesgerichtshof od 24. rujna 2014., odluka br. 2545, cisg-online.ch.

17 Odluka švicarskoga Bundesgericht od 23. rujna 2013., odluka br. 2560., cisg-online.ch. 
ona bila bitna, u sudskoj praksi nalaze se i pojedinačni primjeri bitnih povreda. Takva povreda ugovora neprijeporno postoji kada ugovorna strana u potpunosti propusti ispuniti svoje ugovorne obveze. S tim je usporedivo otvaranje stečaja nad stranom koja je dužna obaviti plaćanje, jer otvaranje stečaja u pravilu pokazuje nesposobnost za plaćanje, ${ }^{18}$ a potpuni izostanak plaćanja predstavlja potpuno neispunjenje. Bitna povreda ugovora zbog potpunog neispunjenja postoji i kad ugovorna strana izjavi da neće ispuniti ugovorne obveze koje još nisu dospjele, uključujući i kupčevu izjavu da neće preuzeti buduću isporuku. ${ }^{19}$ Bitnu povredu ugovora može predstavljati jedna povreda ugovora, ali bitna povreda ugovora može biti rezultat više pojedinačnih povreda od kojih ni jedna sama po sebi nije bitna, no to ne znači da više pojedinačnih povreda, samim time, predstavlja bitnu povredu ugovora. ${ }^{20}$

Subjektivni odnos strane koja je povrijedila ugovor, odnosno pitanje je li ona povrijedila ugovor namjerno, uz grubu nepozornost ili uz običnu nepozornost, kod ocjene o težini povrede ne uzima se u obzir, ${ }^{21}$ jer su njeni odlučni učinci neovisni o subjektivnom odnosu strane prema povredi. Dakle, ni nepostojanje odgovornosti za povredu ne znači da nije bitna, niti da postojanje namjere kod povrede ne znači da je ona bitna. Također, samo po sebi, zakašnjenje s isporukom u pravilu ne predstavlja bitnu povredu ugovora, ali je može predstavljati ako iz ugovora ili okolnosti konkretnoga slučaja proizlazi „da kupac ima naročiti interes za usklađenost s datumom isporuke“ ,22 odnosno ako je ,vrijeme bitno, tj. ako je točna isporuka bila krucijalno važna za kupca i to je bilo očito prodavatelju kod sklapanja ugovora“, ${ }^{23}$ što je uvelike usporedivo s rokom koji je bitan sastojak ugovora prema ZOO-u. Dok samo zakašnjenje s isporukom u pravilu ne predstavlja bitnu povredu ugovora, potpuni izostanak isporuke, primjerice zbog objektivne nemogućnosti ispunjenja, trajne spriječenosti prodavatelja zbog više sile ili izjave prodavatelja da neće isporučiti robu, u pravilu predstavlja bitnu povredu ugovora, kao i isti takav izostanak plaćanja. Isto vrijedi i za kupčevo zakašnjenje; samo zakašnjenje ne predstavlja bitnu povredu ugovora, jer je u slučaju zakašnjenja prodavateljev interes zaštićen obvezom plaćanja kamata, ali ako bi vrijeme plaćanja bilo bitan sastojak ugovora, zakašnjenje bi predstavljalo bitnu povredu ugovora. ${ }^{24}$ Ono može biti i bitan sastojak prema okolnostima, a ne prema ugovoru, primjerice kad je ugovoreno plaćanje pri predaji robe ili dokumenata, a radi se o robi koja brzo propada. Bitnu povredu ugovora može predstavljati i neispunjenje kupčeve obveze

18 Tako odluka Saveznog suda, South Australian District, Adelaide od 28. travnja 1995., odluka br. 218., www.cisg.law.pace.edu.

19 Tako odluka Međunarodnog arbitražnog sudišta ICC 274/1999.

20 Tako odluka njemačkoga Bundesgerichtshof od 3. travnja 1996., odluka br. 135, cisg-online.ch.

21 Tako i Bjoerklund u: UN Convention on Contracts for the International Sale of Goods, Stefan Kröll, Loukas Mistelis i Pilar Perales Viscasillas (München: Verlag C.H. Beck, 2011.), 342.

22 Markus Mueller-Chen u: Commentary on the UN-Convention on the International Sale of Goods (CISG), eds. Peter Schlechtriem i Ingeborg Schwenzer (Oxford: Oxford University Press, 2005.), 778.

23 Bach u: Kroell, Mistelis i Viscasillas, UN Convention on Contracts for the International Sale of Goods, 711. Ovi opisi u bitnom odgovaraju pojmu roka kao bitnog sastojka ugovora i mogućnosti da on proizlazi iz ugovora ili naravi posla iz čl. 361. st. 4. ZOO-a.

24 Schwenzer u: Schlechtriem i Schwenzer, Commentary on the UN-Convention on the International Sale of Goods, 924-926. 
da poduzme mjere i udovolji formalnostima nužnim da bi se omogućilo plaćanje, primjerice propuštanje davanja naloga za otvaranje akreditiva, ako iz toga proizlazi da neće platiti robu. ${ }^{25}$ Isto vrijedi i za nepreuzimanje isporuke; samo zakašnjenje $s$ preuzimanjem u pravilu ne predstavlja bitnu povredu ugovora, nego je predstavlja definitivno nepreuzimanje.

Iz toga proizlazi da pravo jedne strane na jednostrani raskid ugovor može nastati zbog neispunjenja bilo koje primarne obveze druge strane. ${ }^{26}$ To pokazuje da se primarne, odnosno namjeravane, obveze strana ne mogu podijeliti po kriteriju važnosti, nego da su sve jednako važne. Stoga se odredba primjenjuje u slučajevima neispunjenja prodavateljevih obveza da isporuči robu na vrijeme i uopće, da roba bude usklađena, ${ }^{27}$ da na robi ne postoje prava i zahtjevi trećih osoba, ${ }^{28}$ da preda dokumente koji se odnose na robu i da kupcu omogući stjecanje vlasništva na robi i kupčevih obveza da plati cijenu, uključujući i poduzimanje mjera i udovoljavanje formalnostima predviđenim ugovorom ili odgovarajućim zakonima i propisima da bi se omogućilo plaćanje, i preuzme robu, sve u skladu s ugovorom, a podredno ugovoru u skladu s konvencijom.

Uz to, nužno je istaknuti da načelo slobode ugovaranja dovodi do mogućnosti valjanog ugovaranja onih povreda ugovora koje će se smatrati bitnim i time neposredno davati pravo na jednostrani raskid ugovora. Kod toga pravo na jednostrani raskid ugovora ne mora biti navedeno izrijekom, nego je dostatno da ugovor upućuje na zaključak kako je određena obveza toliko važna da njeno neispunjenje predstavlja bitnu povredu ugovora. ${ }^{29}$

Postojanje bitne povrede nužno je sagledati u svjetlu okolnosti svakoga pojedinog slučaja. Naime, koncept bitne povrede ugovora iz Konvencije nepoznat je drugim pravnim poredcima, a definicija je plod kompromisa država ugovornica koje pripadaju različitim pravnim krugovima (civil law i common law). Upravo zbog toga, tu odredbu nije uvijek lako primijeniti i protumačiti. Koncept bitne povrede ugovora ima važnu ulogu u sustavu konvencijskih pravnih sredstava jer se prema ozbiljnosti povrede određuju pravna sredstva na koja ima pravo oštećena strana (v. npr. čl. 46. st. 2., čl. 49. st. 1.a, čl. 51. st. 2., čl. 64. st. 1.a i dr.). ${ }^{30}$

Iz izričaja odredbe jasno proizlazi da je pitanje je li strana koja je povrijedila ugovor predvidjela ili nije predvidjela takve posljedice povrede ugovora faktično, odnosno činjenično, pitanje na koje se odgovara uz primjenu pravila o dokazivanju

25 Tako odluka Vrhovnog suda Queenslanda od 17. studenog 2000., odluka br. 587, cisg-online. ch.

26 Prema čl. 49. (1) Konvencije kupac može izjaviti da raskida ugovor ako je bitna povreda ugovora „neizvršenje bilo koje obveze koju prodavalac ima...“, a prema čl. 64. (1) iste konvencije prodavatelj može izjaviti da raskida ugovor ako je bitna povreda ugovora „neizvršenje bilo koje obveze koju kupac ima...".

27 O pojmu usklađenosti v. niže.

28 O pojmu prava i zahtjeva v. niže.

29 Tako Bach u: Kroell, Mistelis i Viscasillas, UN Convention on Contracts for the International Sale of Goods, 708.

30 Tako i Ratko Brnabić, Raskid ugovora prema Konvenciji Ujedinjenih naroda o ugovorima o međunarodnoj prodaji robe (Bečka konvencija): magistarski rad (Zagreb: Sveučilište u Zagrebu, Pravni fakultet, 2004.), 23. 
činjenica. S druge strane, pitanje je li bi to predvidjela razumna osoba istih svojstava $\mathrm{u}$ istim okolnostima, pitanje je na koje se odgovara procjenom o tome što bi $\mathrm{u}$ istim okolnostima predvidjela razumna osoba. No, bez obzira na to na koji se način odgovara na pitanje, budući da su posljedice predviđanja i predvidivosti iste, važno je naznačiti okolnosti u kojima je prva strana bilo predvidjela ili bi razumna osoba $u$ istim okolnostima mogla predvidjeti da je neka povreda ugovora bitna.

Neprijeporno je da predviđanje ili predvidivost postoji kad „bitnost“ obveze proizlazi iz ugovora tako što ugovor za određenu obvezu ili štogod u vezi s njenim ispunjenjem koristi riječi iz kojih to jasno proizlazi, primjerice kad naglašava kako je bitno da je isporuka izvršena najkasnije do određenog dana ili kad naglašava da je vrijeme ispunjenja ili štogod drugo bitan uvjet ugovora. U takvim slučajevima strana koja je povrijedila ugovor ne može tvrditi da nije predvidjela ikakvo oštećenje

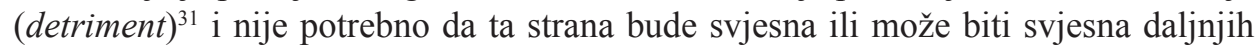
posljedica povrede. To znači da je za bitnu povredu ugovora dostatno da je rok za ispunjenje ugovoren kao esencijalan, a nije nužno da je strana svjesna obveze druge strane da trećoj osobi isporuči robu ili da plati penale. ${ }^{32}$ Isto vrijedi i kad je posebna važnost obveze istaknuta tijekom pregovora, iako možda nije naglašena u ugovoru. ${ }^{33}$ Kad predvidivost ne proizlazi ni iz ugovora ni iz pregovora na nju ukazuju okolnosti konkretnog slučaja. Prema sudskim odlukama, primjerice, ako prodavatelj ne može isporučiti robu jer ju je prodao trećoj osobi, mora razumno očekivati je obveza koju je povrijedio od središnje važnosti za kupca, ${ }^{34}$ kao i u slučaju isporuke sezonske robe nakon proteka sezone. ${ }^{35}$

Dok njemački i švicarski sudovi zauzimaju strogi pristup definiciji pojma bitne povrede, i raskid ugovora dopuštaju samo kao posljednje sredstvo (ultima ratio), kada niti jedno drugo sredstvo nije moguće (zamjena stvari, popravak, sniženje cijene), sudovi Francuske, Austrije i Sjedinjenih Američkih Država zauzeli su fleksibilniji pristup kod utvrđivanja bitne povrede i vrlo često raskid ugovora dopuštaju i kada je povredu moguće sanirati nekim drugim sredstvom. Do ovakve divergentne prakse vrlo često dolazi kada sudovi Konvenciji ne pristupaju kao autonomnom instrumentu, već njegove odredbe tumače kroz prizmu nacionalnog prava. ${ }^{36}$

Osim dospijeća obveze i neispunjenja te obveze o dospijeću, okolnost da neispunjenje predstavlja bitnu povredu ugovora jedina je pretpostavka nastanka prava na jednostrani raskid ugovora i ono nastaje čim nastane takva povreda ugovora, što znači da je tada isključena potreba davanja naknadnoga roka za ispunjenje ili poduzimanja neke druge radnje, nego savjesna strana može odmah izjaviti da raskida ugovor. ${ }^{37}$ Istovremeno izričaji odredbi čl. 49. st. 1. (a) i čl. 64. st. 1. (a) Konvencije

31 Tako odluka Audiencia Provincial Madrid od 20. veljače 2007., odluka br. 1637., cisg-online. ch.

32 Tako odluka Oberlandesgericht Koeln od 24. travnja 2013., odluka br. 2480, cisg-online.ch.

33 Tako odluka Međunarodnog arbitražnog sudišta ICC 8128/1995, odluka br. 526, cisg-online.ch.

34 Odluka Oberlandesgericht Duesseldorf od 17. studeni 1983., odluka br. 6, cisg-online.ch.

35 Odluka Corte d'Appello Milano od 20. ožujka 1998., odluka br. 348, cisg-online.ch.

36 Tako i Schlechtriem i Butler, UN Law on International Sales - The UN Convention on the International Sale of Goods, 100.

37 Tako i Bell u: Kroell, Mistelis i Viscasillas, Kroell, Mistelis i Viscasillas, UN Convention on 
upućuju na to da se ugovor sigurno raskida samo izjavom, odnosno očitovanjem volje riječima, jer spominju samo izjavu, a ne i druge načine očitovanja volje, iako u sudskoj praksi postoje i odluke prema kojima bi to bilo moguće i takvim konkludentnim radnjama koje jasno pokazuju namjeru raskidanja ugovora. ${ }^{38}$ Izjava o raskidu ne mora sadržavati upravo izraz raskid, nego je dostatno da jasno pokazuje kako strana koja izjavljuje raskid neće ispuniti ugovor zbog povrede druge strane. ${ }^{39}$ Prema čl. 26. Konvencije ugovor će biti raskinut $u$ trenutku kad je druga strana obaviještena o toj izjavi, točnije govoreći kad je primila očitovanje o raskidu prve strane. ${ }^{40}$

\section{RASKID ZBOG NEISPUNJENJA U DODATNOM ROKU}

Prema čl. 49. (1) (b) Konvencije „kupac može izjaviti da raskida ugovor... u slučaju neisporuke, ako prodavalac nije isporučio robu u dodatnom roku koji mu je kupac odredio... ili je izjavio da je neće isporučiti u tako određenom roku“, a prema čl. 64. (1) (b) Konvencije „prodavalac može izjaviti da raskida ugovor... ako kupac nije ni u dodatnom roku što ga je odredio prodavalac... izvršio svoju obvezu da plati cijenu ili preuzme isporuku robe, ili je izjavio da to neće učiniti u tako određenom roku“.

Odredbe čl. 47. i čl. 63. Konvencije potpuno istovjetnim riječima utvrđuju da kupac prodavatelju, odnosno prodavatelj kupcu, „može odrediti... dodatni rok... za izvršenje njegovih obveza“, iz čega bi se moglo zaključiti da strane potpuno slobodno odlučuju o davanju drugoj strani dodatnog roka za ispunjenje obveza. Takav bi zaključak bio pogrešan, jer samim neispunjenjem druge strane do isteka roka za ispunjenje ugovor se ni u jednom slučaju ne raskida eo ipso, a jednostrano može biti raskinut samo ako takvo neispunjenje predstavlja bitnu povredu ugovora. Kako situacije u kojima takvo neispunjenje predstavlja bitnu povredu ugovora nisu česte, kako često nije posve izvjesno hoće li neko neispunjenje predstavljati takvu povredu, i kako u slučaju neispunjenja u dodatnom roku za jednostrani raskid ugovora povreda ugovora ne treba biti bitna, nerijetko će biti razumno drugoj strani ostaviti dodatni rok za ispunjenje. Osim toga, kad se radi o prodavateljevu neispunjenju do isteka roka, izričita odredba Konvencije propisuje da ,prodavalac može, čak i nakon proteka roka za isporuku, na svoj trošak otkloniti svako neizvršenje svojih obveza“", ${ }^{41}$ što je moguće uvijek osim ako bi neispunjenje do isteka roka za ispunjenje predstavljalo bitnu povredu ugovora i kupac bi ga odmah raskinuo. ${ }^{42}$

Contracts for the International Sale of Goods, 841 i Knapp u: Bianca i Bonell, Commentary on the International Sales Law, 468.

38 Tako odluka austrijskog Oberste Gerichtshof od 5. srpnja 2000., odluka br. 652, www.cisg.law. pace.edu.

39 Tako Bach u: Kroell, Mistelis i Viscasillas, UN Convention on Contracts for the International Sale of Goods, 721.

40 Prema čl. 26. Konvencije „Izjava o raskidu ugovora ima učinak jedino ako je o njoj obaviještena druga strana".

41 Čl. 48. (1) Konvencije.

42 Tako i Nina Tepeš i Stjepan Šutija, „Bitna povreda ugovora i pravo prodavatelja na otklanjanje neispunjenja u naknadnom roku prema Konvenciji UN-a o ugovorima o međunarodnoj prodaji 
Kao što je već spomenuto, glavna razlika glede pretpostavki jednostranog raskida ugovora zbog neispunjenja u dodatnom roku i jednostranog raskida ugovora zbog bitne povrede ugovora upravo je u tome što je za jednostrani raskid ugovora zbog neispunjenja $u$ dodatnom roku potrebno samo da druga strana ne ispuni obvezu isporuke robe, odnosno plaćanja cijene ili/i preuzimanja isporuke robe ili da izjavi da je neće ispuniti.

Kao i odredbe Konvencije koje sadrže pravilo o jednostranom raskidu ugovora zbog bitne povrede, i ove odredbe podrazumijevaju da druga strana o dospijeću nije ispunila svoju obvezu, ali s time što se ovdje radi o tome da kupac o dospijeću nije ispunio obvezu plaćanja cijene ili preuzimanja isporuke, odnosno prodavatelj obvezu isporuke robe, pa kad povreda ugovora nije bitna prodavatelju pripada pravo na jednostrani raskid ugovora samo zbog kupčevog neispunjenja obveze plaćanja cijene $\mathrm{i} /$ ili preuzimanja isporuke robe, odnosno kupcu samo zbog neispunjenja obveze isporuke robe, dok prema pravilu o jednostranom raskidu zbog bitne povrede ugovor može biti raskinut zbog neispunjenja bilo koje obveze druge strane. ${ }^{43}$

Citirane odredbe čl. 49. (1) (b) i čl. 64. (1) (b) Konvencije ne spominju dužinu dodatnog roka, nego upućuju na dodatni rok koji je „kupac odredio na temelju stava 1. člana 47.“, odnosno „prodavalac, u skladu sa stavom 1. člana 63.“. Prema prvoj od tih odredbi „kupac može odrediti prodavaocu dodatni rok razumne dužine“, a istovjetno i prema drugoj, jer i prodavatelj ,,može odrediti kupcu dodatni rok razumne dužine za izvršenje njegovih obveza“". Kao i u brojnim drugim situacijama u kojima je zbog iznimne širine i različitosti životnih okolnosti nemoguće rok odrediti u danima ili nekim drugim vremenskim jedinicama, i ovdje nije bilo moguće učiniti drukčije. Gotovo da nije potrebno reći kako se na pitanje je li rok koji je strana odredila razuman ili nije, odgovara s obzirom na okolnosti konkretnog slučaja. Razumnim treba uzeti onaj rok koji je u tim okolnostima dostatan za to da drugoj strani objektivno bude moguće ispuniti neispunjenu obvezu. Odredbe Konvencije ne daju izričiti odgovor na pitanje posljedica određivanja roka kraćeg od razumnoga u konkretnim okolnostima. Ali, s obzirom na izloženi zaključak o postojanju prava na naknadni rok kad povreda ugovora nije bitna i okolnost da bi to pravo izgubilo svoju svrhu kad bi ugovorna strana mogla raskinuti ugovor prije isteka roka koji je dostatno dug da druga strana $u$ tom roku može ispuniti obvezu, smatramo da drugoj strani pripada razuman rok i da prodavatelj ne može valjano raskinuti ugovor prije njegova isteka i u slučaju kad je odredio kraći rok od razumnoga. ${ }^{44}$

Dodatni rok ne treba računati od trenutka isteka prvobitnog roka za ispunjenje, nego od obavijesti o tom roku. Kad istekne ugovorna strana može raskinuti ugovor izjavom za koju vrijedi ono što je izloženo u prikazu jednostranog raskida zbog bitne povrede ugovora.

Citirani čl. 49. (1) (b) i čl. 64. (1) (b) Konvencije mogućnost jednostranog raskida ugovora prve strane ne veže samo uz istek dodatnog roka za ispunjenje, nego

robe“, Pravo i porezi 20, br. 5. (2011.): 14-23.

43 Tako i Brnabić, Raskid ugovora prema Konvenciji Ujedinjenih naroda o ugovorima o međunarodnoj prodaji robe, $42-47$ i 91.

44 Prema Bell u: Kroell, Mistelis i Viscasillas, UN Convention on Contracts for the International Sale of Goods, 838, ovo shvaćanje prevladava i u literaturi. 
i uz držanje druge strane, jer prva strana može raskinuti ugovor, ne samo kad istekne dodatni rok, nego i kad druga strana izjavi da neispunjenu obvezu neće ispuniti u dodatnom razumnom roku. Doslovno tumačenje ovih odredbi Konvencije značilo bi da prodavatelj može raskinuti ugovor samo ako kupac izričito riječima ukaže na to da obvezu plaćanja ili preuzimanja isporuke neće ispuniti ni u naknadnom roku, ali to nije nužno, nego je dostatno da iz njegove izjave proizlazi zaključak o odbijanju ispunjenja. ${ }^{45}$ Iz izričaja čl. 49. (1) (b) i čl. 64. (1) (b) Konvencije mogao bi proizlaziti zaključak da one opisuju samo situacije u kojima je jedna strana prvo drugoj odredila dodatni rok, a druga nakon toga izjavila da neće ispuniti obvezu u tom roku, pa je moguće postaviti pitanje učinaka izjave druge strane da neće ispuniti obvezu, koja je dana prije no što je prva strana odredila dodatni rok ili ga uopće nije odredila. Budući da je ostavljanje dodatnog roka izlišno uvijek kad je potpuno jasno da druga strana ni u tom roku neće ispuniti obvezu, držimo da je racionalno stajalište u skladu sa svrhom odredbi konvencije o raskidu ugovora da prva strana stječe pravo jednostrano raskinuti ugovor čim, nakon neispunjenja druge strane o dospijeću, primi kupčevu izjavu da neće ispuniti obvezu. ${ }^{46} \mathrm{U}$ tim okolnostima ne vidimo koji bi bio opravdani i racionalni razlog zahtijevao dodatni rok ili istek već određenoga dodatnog roka.

Učinak određivanja dodatnog roka za ispunjenje je i suspenzija drugih sredstava predviđenih za slučaj povrede ugovora do isteka tog roka. To znači da do isteka tog roka strana ne može, ne samo raskinuti ugovor, nego ni zahtijevati ispunjenje, ali samo ako ne primi obavijest druge strane da neće ispuniti obvezu u dodatnom roku. ${ }^{47}$ Iznimno od toga, suspenzija ne obuhvaća pravo na naknadu štete, jer objema stranama i dalje pripada pravo zahtijevati naknadu štete zbog zakašnjenja, ako bi je pretrpjele zbog zakašnjenja.

\section{RASKID ZBOG NEUSKLAĐENOSTI}

Prema naslovu Odsjeka II, Glave II, III. Dijela, Odsjek II uređuje „Usklađenost robe i prava ili potraživanja trećih osoba“, a prema prvoj odredbi tog Odsjeka „Prodavalac je dužan isporučiti robu u količini, kvaliteti i vrsti kako je to predviđeno

45 Prema stajalištu odluke švicarskoga Bundesgerichta 20. prosinca 2006., odluka br. 1426. www. cisg.law.pace.edu, odbijanje postoji i kad je ispunjenje ponuđeno, ali je uvjetovano zahtjevom za ispunjenje obveze druge strane, na koji prva strana nije ovlaštena.

46 U bitnom tako i Bell u: Kroell, Mistelis i Viscasillas, UN Convention on Contracts for the International Sale of Goods, 841.

47 Prema čl. 47. (2) Konvencije „Osim ako kupac primi obavijest od prodavaoca da on neće izvršiti svoje obveze do proteka tog roka, kupac se ne može u tom roku koristiti bilo kojim sredstvom predviđenim za povredu ugovora. Kupac, međutim, ne gubi zbog toga pravo da zbog zakašnjenja prodavaoca zahtijeva naknadu štete“, a prema čl. 63. (2) Konvencije „Ako prodavalac ne primi obavijest od kupca da neće izvršiti svoje obveze u roku koji je tako određen, prodavalac se ne može do proteka tog roka koristiti bilo kojim sredstvom predviđenim za slučaj povrede ugovora. Prodavalac, Međutim, ne gubi zbog toga pravo da zbog zakašnjenja kupca zahtijeva naknadu štete“. Budući da prema engleskom izvorniku „the seller may not, during that period, resort to any remedy for breach of contract", nije riječ o tome da se prodavatelj ne može koristiti bilo kojim sredstvom, nego niti jednim sredstvom, a isto vrijedi i za kupca. 
ugovorom te pakiranu ili zaštićenu na način predviđen ugovorom“. ${ }^{48}$ Ona, dakle, ne spominje samo količinu i kvalitetu robe, nego i njenu vrstu, kojom je riječju preveden izraz opis (engl. description) iz engleskog izvornika. Stoga je prodavatelj dužan isporučiti robu koja odgovara opisu kako je to predviđeno ugovorom, odnosno čiji identitet odgovara identitetu robe prema ugovoru. Uvrštenjem u jednu odredbu naloga prodavatelju da isporuči robu čiji identitet, kvaliteta i količina su u skladu s ugovorom Konvencija je izbrisala razliku između neispunjenja predajom druge stvari umjesto ugovorene $\mathrm{i}$ ispunjenja s nedostatcima kakva postoji prema ZOO-u i istom pravnom režimu podvrgnula slučajeve u kojima je isporučen aliud i slučajeve u kojima je isporučen odgovarajući predmet, ali s nedostatcima.

Glavna je posljedica toga što je i u slučaju isporuke aliud, za očuvanje kupčevih prava potrebno kupčevo obavješćivanje prodavatelja o nedostatku usklađenosti, ${ }^{49} \mathrm{osim}$ ako je prodavatelj znao za neusklađenost ili mu ona nije mogla biti nepoznata. ${ }^{50}$ Znači da je pravovremeno obavješćivanje o neusklađenosti u pravilu, prva pretpostavka prava na jednostrani raskid ugovora zbog nedostataka. ${ }^{51}$

Druga pretpostavka raskida ugovora zbog neusklađenosti robe jednostranim očitovanjem volje kupca je pravovremeno davanje izjave o raskidu. Pravovremeno znači u razumnom roku, koji počinje teći ovisno o okolnostima. Konvencija razlikuje i odvojeno navodi tri različite situacije koje određuju trenutak početka tijeka razumnoga roka za raskid ugovora jednostranim očitovanjem volje kupca. Nakon trenutka u kojem je kupac otkrio neusklađenost robe, on ne mora, ali može, odrediti prodavatelju dodatni rok razumne dužine za ispunjenje njegovih obveza, ${ }^{52}$ dakle za postizanje usklađenosti isporuke, ali i prodavatelj može od kupca zahtijevati da se izjasni prihvaća li ispunjenje ugovora u određenom roku i ispuniti ugovorne obveze u tom roku ako kupac ne odbije njegov zahtjev. ${ }^{53}$ Imajući u vidu ove mogućnosti razuman rok za izjaviti raskid ugovora teče od trenutka u kojem je kupac saznao ili morao saznati za neusklađenost, ili od trenutka isteka dodatnog roka koji je odredio kupac, ili od trenutka isteka dodatnog roka koji je odredio prodavatelj.

Međutim, nakon što kupac obavijesti prodavatelja o dodatnom roku što ga je odredio, prodavatelj može obavijestiti kupca da neće ispuniti svoje obveze u tom roku, a nakon što prodavatelj zahtijeva očitovanje kupca o tome prihvaća li ispunjenje u dodatnom roku koji je odredio prodavatelj, kupac može izjaviti da ga ne prihvaća. Stoga, osim od navedenih trenutaka razuman rok za izjaviti raskid ugovora može teći i od trenutka kad je prodavatelj obavijestio kupca da neće ispuniti svoje obveze

48 Čl. 35. st. 1. Konvencije.

49 Prema čl. 39. (1) Konvencije: „Kupac gubi pravo pozivati se na nedostatak usklađenosti robe ako o tome nije prodavaocu poslao obavijest u kojoj je naveo narav nedostatka, u razumnom roku od trenutka kada ga je otkrio ili morao otkriti“, a prema čl. 39. (2) Konvencije: „kupac u svakom slučaju gubi pravo pozvati se na nedostatak usklađenosti robe ako o njemu nije obavijestio prodavaoca najkasnije u roku od dvije godine, računajući od dana stvarne predaje robe kupcu, osim kad taj rok nije u skladu s rokom u ugovornoj garanciji“.

50 Čl. 40. Konvencije.

51 Tako i Mueller-Chen u: Schlechtriem i Schwenzer, Commentary on the UN-Convention on the International Sale of Goods, 779.

52 Čl. 47. st. 1. Konvencije.

53 Čl. 48. st. 2. Konvencije. 
u dodatnom roku koji je odredio kupac te od trenutka kad je kupac izjavio da neće prihvatiti ispunjenje $\mathrm{u}$ dodatnom roku koji je odredio prodavatelj. ${ }^{54}$

Kao što ni druge povrede ugovora same po sebi i uvijek ne moraju biti bitne, tako ne mora nužno biti bitna ni povreda ugovora koja se sastoji u nedostatku usklađenosti, a kao što je i inače za raskid ugovora nužno da povreda bude bitna, tako i nedostatak usklađenosti treba predstavljati bitnu povredu ugovora. Načelno govoreći takvu povredu nedostatak usklađenosti predstavlja kad je nedostatak objektivno ozbiljan i kad ga kupac nije otklonio, ${ }^{55}$ odnosno kad zbog povrede ugovora neusklađenošću kupac izgubi interes za ispunjenje. ${ }^{56}$ To podrazumijeva da prema Konvenciji prodavatelju u pravilu pripada naknadni rok za postizanje usklađenosti ili usklađenu isporuku, pa u pravilu kupac može jednostrano raskinuti ugovor tek ako prodavatelj nije postigao usklađenost u razumnom roku. ${ }^{57}$ Iznimno, ugovor može biti raskinut i prije isteka razumnoga roka ako su nedostatci takvi da ne mogu biti otklonjeni u tom roku, niti u tom roku prodavatelj može isporučiti robu bez nedostataka. Isto vrijedi i ako je usklađena isporuka do isteka ugovorenog roka isporuke bila bitni sastojak ugovora, pa njenim izostankom u ugovorenom roku nastaje bitna povreda ugovora, a također i ako je prodavatelj ozbiljno i definitivno odbio otkloniti neusklađenost, odnosno izvršiti usklađenu isporuku.

\section{RASKID ZBOG PRAVA ILI POTRAŽIVANJA TREĆE OSOBE}

Kao što ne poznaje pojam materijalnih nedostataka, Konvencija ne poznaje ni pojam pravnih nedostataka, nego nalaže prodavatelju da isporuči robu slobodnu „od prava ili potraživanja treće osobe“, 58 što je fraza koja potječe iz izvornog teksta Konvencije na engleskom jeziku, koji govori o right or claim treće osobe. ${ }^{59}$

Potraživanje ili tražbina je subjektivno obvezno pravo, koje djeluje samo između strana u obvezno pravnom odnosu, a ne i prema trećima. Takvo djelovanje odgovara načelu relativnosti, koje je usporedivo s pojmovima privity of contract $\mathrm{i}$ right in personam $\mathrm{u}$ common lawu. ${ }^{60}$ Stoga i eventualna obvezno pravna potraživanja

54 Ovo sve proizlazi iz čl. 49. st. 2. Konvencije, prema kojem: ,kupac gubi pravo raskinuti ugovor ako to nije učinio... u razumnom roku... (i) nakon što je saznao ili morao saznati za povredu, (ii) nakon proteka svakoga dodatnog roka što ga je kupac odredio u skladu sa stavkom 1. članka 47, ili nakon što je prodavalac izjavio da neće izvršiti svoje obveze u ovome dodatnom roku; ili (iii) nakon proteka svakoga dodatnog roka što ga je odredio prodavalac u skladu sa stavkom 2. članka 48. ili nakon što je kupac izjavio da neće prihvatiti izvršenje“.

55 Tako i Mueller-Chen u: Schlechtriem i Schwenzer, Commentary on the UN-Convention on the International Sale of Goods, 779 i tamo navedena literatura i sudska praksa.

56 Tako odluka njemačkoga Bundesgerichtshoaf od 24. rujna 2014., odluka br. 2545, cisg-online. ch.

57 Tako odluka Handelsgericht Aargau od 5. studeni 2002., odluka br. 715, cisg-online.ch.

58 Čl. 41. Konvencije, prva rečenica.

59 Prema engleskom izvorniku početni dio prve rečenice čl. 41. Konvencije glasi: „The seller must deliver goods which are free from any right or claim of a third party..."

60 Za pojam privity of contract, v. Black's, 1237, a za razlikovanje pojmova rights in personam i rights in rem, v. Ivana Tucak, „Pravni odnosi in rem i pravni odnosi in personam“, Pravni vjesnik 27, br. 2 (2011.): 7-22. 
koja treće osobe mogu imati prema prodavatelju, djeluju samo prema njemu, a ne i prema kupcu, pa obvezno pravna potraživanja trećih osoba prema prodavatelju ne mogu utjecati na pravni položaj kupca i predstavljati pravni nedostatak. Ali, kad trećoj osobi pripada pravo koje djeluje erga omnes (prema svima), što je usporedivo s rights in rem common lawa, ${ }^{61}$ poput stvarnih prava i prava intelektualnog vlasništva, ono će djelovati i utjecati i na pravni položaj kupca i predstavljat će pravni nedostatak. Stoga „potraživanje“ u citiranom izrazu Konvencije ne treba shvatiti kao obvezno pravnu tražbinu koja bi potjecala iz odnosa prodavatelja i treće osobe, nego kao zahtjev treće osobe koji proizlazi iz onog njegovog prava koje djeluje prema svima i koji može biti upravljen prema kupcu.

U literaturi se, međutim, navodi kako uključivanje pojma potraživanja u pojam pravnog nedostatka znači da pojam pravnog nedostatka ne obuhvaća samo stvarno postojeća prava trećih osoba, nego i situacije u kojima bi treće osobe prema kupcu postavile zahtjeve, pri čemu je nebitno jesu li oni osnovani, odnosno ima li treća osoba zaista neko pravo. ${ }^{62}$ Prodavateljeva povreda ugovora postojala bi, prema tome, ne samo kad trećoj osobi pripada neko pravo koje utječe na kupca, nego i čim bi treća osoba postavila neki zahtjev prema kupcu, što se obrazlaže stajalištem da je normalno očekivanje kupca kako povodom kupnje neće biti uvučen u spor s trećom osobom. ${ }^{63}$ Osim toga, Konvencija izrijekom spominje i zasebno uređuje situacije u kojima se pravo ili potraživanje treće osobe temelji na industrijskom ili drugom intelektualnom vlasnišstvu. ${ }^{64}$

Konvencija, izuzevši jedno, ${ }^{65}$ ne sadrži posebna pravila o jednostranom raskidu ugovora zbog prava ili potraživanja trećeg, pa i na jednostrani raskid. Zbog toga treba primijeniti opće pravilo prema kojem postojanje prava ili potraživanja trećeg treba predstavljati bitnu povredu ugovora, kako bi mogao biti jednostrano raskinut bez ostavljanja primjerenoga naknadnog roka za ispunjenje, odnosno za prodavateljevo otklanjanje prava ili potraživanja trećeg ili isporuku slobodnu od prava ili potraživanja trećeg. ${ }^{66}$ Takva povreda ne nastaje samim time što postoji bilo kakvo pravo ili potraživanje treće osobe, nego ako trećem pripada pravo zahtijevati trenutnu predaju robe ili spriječiti kupca da robu koristi prema ugovoru, a oslobođenje od tog prava nije moguće ni za kupca razumno. ${ }^{67} \mathrm{~S}$ druge strane bitna povreda ugovora ne postoji kad kupac u razumnom roku može osigurati korištenje robe tako što ju je oslobodio prava ili potraživanja trećeg, a prodavatelj je kupcu dao dostatno osiguranje ili kupac može

61 Tucak, Pravni odnosi in rem i pravni odnosi in personam: 7-22.

62 Schwenzer u: Schlechtriem i Schwenzer, Commentary on the UN-Convention on the International Sale of Goods, 685 i Date-Bah u: Bianca-Bonell, 318.

63 Kroell u: Kroell, Mistelis i Viscasillas, UN Convention on Contracts for the International Sale of Goods, 629.

64 Čl. 41., druga rečenica i čl. 42. Konvencije, koji određuje situacije u kojima postoje prava intelektualnog vlasništva, bez kojih je prodavatelj dužan isporučiti robu.

65 Riječ je o čl. 43. Konvencije o kojem v. niže pod „Gubitak prava na raskid“.

66 Tako Kroell u: Kroell, Mistelis i Viscasillas, UN Convention on Contracts for the International Sale of Goods, 635.

67 Tako Schwenzer u: Schlechtriem i Schwenzer, Commentary on the UN-Convention on the International Sale of Goods, 690. 
prebiti svoju tražbinu s prodavateljevom tražbinom isplate cijene. ${ }^{68}$

\section{POTPUNI I DJELOMIČNI RASKID}

Pravne posljedice situacija u kojoj bi prodavatelj isporučio samo dio robe ili bi samo jedan dio robe bio usklađen s ugovorom Konvencija uređuje u čl. 51. tako što propisuje da će se odredbe o sredstvima kojima raspolaže kupac u slučaju prodavateljeve povrede ugovora primijeniti ,u pogledu dijela koji nedostaje ili koji nije u skladu s ugovorom“69 te da „kupac može izjaviti da raskida cijeli ugovor samo ako djelomično neizvršenje ili nedostatak usklađenosti predstavlja bitnu povredu ugovora"70 I ovdje je Konvencija dosljedna u primjeni kriterija „bitne povrede ugovora“, pa ugovor može jednostrano biti raskinut u cjelini samo ako djelomično neispunjenje ili djelomična neusklađenost predstavlja takvu povredu ugovora.

Kao što je i pravilo o mogućnosti jednostranog raskida samo do isteka razumnoga roka od odgovarajućih događaja upravljeno na očuvanje ugovora kad god je to moguće, odnosno na ostvarenje načela favor negotii, tako je na to upravljeno pravilo o nužnosti bitne povrede ugovora kao pretpostavci raskida čitavog ugovora zbog djelomičnog neispunjenja ili djelomične neusklađenosti. ${ }^{71}$

\section{RASKID KOD UZASTOPNIH ISPORUKA}

Kupoprodajni ugovori, posebno trgovački, nerijetko sadrže prodavateljevu obvezu da ugovorenu robu ne isporuči odjednom, nego da je isporučuje uzastopno, u nekim rokovima odnosno u nekim razdobljima nakon sklapanja ugovora. Katkad takvoj obvezi prodavatelja odgovara kupčeva obveza plaćanja svake pojedine isporuke, pa je jednostrani raskid ugovora s uzastopnim isporukama moguć ne samo zbog prodavateljeve povrede ugovora, nego i zbog kupčeve povrede ugovora, iako bi uporaba izraza ,isporuka“ navodila na pomisao kako je riječ samo o uzastopnim obvezama prodavatelja. To jasno proizlazi iz čl. 73. st. 1. Konvencije, koji govori o neispunjenju obveza jedne strane,$^{72}$ a ne o neispunjenju prodavateljevih obveza, pa to može biti i jedna i druga strana. ${ }^{73}$ Ova odredba Konvencije o neispunjenju „bilo koje obveze jedne strane koja se odnosi na jednu isporuku“ što preciznije i jasnije opisuje stanje koje se uređuje tim odredbama. Naime, primjerice govoreći, prodavateljeva obveza nije samo predaja, odnosno isporuka, robe, nego i omogućavanje kupcu da stekne vlasništvo na robi, pa obje odredbe uređuju situacije u kojima bilo koja od tih obveza nije ispunjena.

68 Tako Kroell u: Kroell, Mistelis i Viscasillas, UN Convention on Contracts for the International Sale of Goods, 635.

69 Čl. 51. (1) Konvencije.

70 Čl. 51. (2) Konvencije.

71 Tako i Will u: Bianca i Bonell, Commentary on the International Sales Law, 378.

72 Prema relevantnom dijelu čl. 73. (1) Konvencije: „Ako je u slučaju ugovora s uzastopnim isporukama neizvršenje bilo koje obveze jedne strane koja se odnosi na jednu isporuku...".

73 O raskidu ugovora s uzastopnim obvezama, v. više u Brnabić, Raskid ugovora prema konvenciji Ujedinjenih naroda o ugovorima o međunarodnoj prodaji robe (Bečka konvencija), 58. 
I kad se radi o vremenskom dosegu učinaka jednostranog raskida izričaj odredbi Konvencije jasan je i precizan. Naime, Konvencija izrijekom najprije određuje da „druga strana može izjaviti da raskida ugovor u odnosu na tu isporuku“ “74 a u drugoj odredbi da druga strana „može izjaviti da ugovor raskida za ubuduće“ ${ }^{75}$ pod pretpostavkom da ,osnovano može zaključiti da će se bitno povrijediti ugovor prema budućoj isporuci“. ${ }^{76}$

Katkad sve uzastopne isporuke, odnosno obveze, čine jednu cjelinu, pa Konvencija sadrži posebna rješenja o vremenskom dosegu učinaka jednostranog raskida u takvim slučajevima. Ali ona ne govori o cjelini svih uzastopnih isporuka, nego o međuovisnosti isporuka, tako da je jednostrani raskid ugovora ab ovo moguć samo ako su sve uzastopne isporuke međuovisne. ${ }^{77}$ Glede novčanih obveza prema Konvenciji pravilo o obvezi primanja djelomičnog ispunjenja vrijedi beziznimno jer odredba koja uređuje raskid ugovora $a b$ ovo polje primjene ograničava na kupca, odnosno na njegovo pravo na jednostrani raskid ugovora $a b$ ovo. ${ }^{78}$ To, tumačenjem $a$ contrario, dovodi do zaključka da prodavatelj ne bi imao pravo raskinuti ugovor $a b$ ovo zbog izostanka jednog od više ugovorenih uzastopnih plaćanja.

\section{GUBITAK PRAVA NA RASKID}

Kao što su i odredbe o jednostranom raskidu ugovora u Konvenciji strukturirane tako da je prodavateljevo pravo na jednostrani raskid ugovora uređeno odvojeno od kupčevog prava na jednostrani raskid ugovora, pri čemu su ta prava uređena bitno istovjetno uvijek kad to dopušta priroda obveze jedne odnosno druge strane, tako su strukturirane i odredbe o gubitku prava. Kupčev gubitak prava kad je prodavatelj isporučio robu uređen je u čl. 49. (2), a prodavateljev kad je kupac platio cijenu u čl. 64. (2) Konvencije, ali na sličan način. ${ }^{79}$

Kad je prodavatelj isporučio robu, odnosno kupac platio cijenu u cijelosti, ${ }^{80}$ Konvencija odvojeno uređuje gubitak prava raskinuti ugovor zbog zakašnjenja $\mathrm{s}$ isporukom, odnosno plaćanjem, od gubitka prava raskinuti ugovor zbog druge

74 Čl. 73. st. 1. Konvencije in fine: „Ako je u slučaju ugovora s uzastopnim isporukama neizvršenje bilo koje obveze jedne strane koja se odnosi na jednu isporuku bitna povreda ugovora u vezi s tom isporukom, druga strana može izjaviti da raskida ugovor u odnosu na tu isporuku“.

75 Dio čl. 73. (2) Konvencije, koji u cijelosti glasi: „Ako zbog neizvršenja bilo koje obveze jedne strane u odnosu bilo na koju uzastopnu isporuku druga strana osnovano može zaključiti da će se bitno povrijediti ugovor prema budućoj isporuci, ta strana može izjaviti da ugovor raskida za ubuduće, iz uvjet da to učini u razumnom roku“".

76 Dio čl. 73. (2).

77 Čl. 73. st. 3. Konvencije: „Kupac koji raskida ugovor bilo zbog koje isporuke može istovremeno izjaviti da raskida ugovor za već primljene isporuke ili za buduće isporuke, ako se zbog njihove međuovisnosti ove isporuke ne bi mogle koristiti u svrhu koju su strane imale na umu pri sklapanju ugovora".

78 Prema početnom dijelu 73. st. 3. Konvencije „Kupac koji raskida ugovor...“.

79 Tako i Brnabić, Raskid ugovora prema Konvenciji Ujedinjenih naroda o ugovorima o međunarodnoj prodaji robe (Bečka konvencija), 78 i 95.

80 Prema Knappu: Bianca i Bonell, Commentary on the International Sales Law, 470 djelomično plaćanje ne dovodi do primjene pravila koja se prikazuju. 
povrede ugovora.

Kad je prodavatelj ispunio obvezu isporuke robe, kupac gubi pravo raskinuti ugovor zbog zakašnjenja s isporukom, ako to nije učinio u razumnom roku računajući od trenutka kad je saznao da je isporuka izvršena, a kad je kupac ispunio obvezu plaćanja u cijelosti, prodavatelj gubi pravo raskinuti ugovor zbog zakašnjenja $\mathrm{s}$ plaćanjem, ako ga nije raskinuo prije nego što je saznao za plaćanje. ${ }^{81}$ Naime via facti je moguće da prodavatelj isporuči robu nakon isteka razumnoga naknadnog roka, koji mu je ostavio kupac, ali ujedno prije no što je kupac izjavio da raskida ugovor, odnosno da kupac plati robu nakon isteka razumnoga naknadnog roka koji mu je ostavio prodavatelj.

Kad je prodavatelj ispunio obvezu isporuke robe, odnosno kad je kupac platio cijenu, druga strana gubi pravo raskinuti ugovor zbog druge povrede ugovora, ako to nije učinila u razumnom roku računajući od trenutka kad je saznala ili morala saznati za tu drugu povredu ugovora. ${ }^{82}$

Ako je druga strana odredila dodatni rok za ispunjenje, u situaciji u kojoj je prodavatelj ispunio obvezu isporuke robe, odnosno kupac obvezu plaćanja cijene, druga strana gubi pravo raskinuti ugovor zbog druge povrede ugovora, ako to nije učinila u razumnom roku nakon proteka dodatnog roka ili nakon izjave prve strane da neće ispuniti svoje obveze u tom dodatnom roku. ${ }^{83}$ Izričaj odredbi Konvencije upućuje na to da bi drugu povredu ugovora, osim zakašnjenja, predstavljali neispunjenje $u$ dodatnom roku i kupčeva izjava da neće ispuniti obvezu u tom roku. U tim slučajevima, ako je cijena plaćena do trenutka kad istječe razumni rok, koji počinje teći od isteka dodatnog roka ili kupčeve izjave da neće ispuniti obveze u tom roku, istekom tog razumnoga roka prodavatelj gubi pravo jednostrano raskinuti ugovor. Primjerice, ako kupac nije preuzeo robu u dodatnom roku ili je izjavio da to neće učiniti, prodavatelj gubi pravo jednostrano raskinuti ugovor istekom razumnoga roka, od prvog od ta dva događaja, podrazumijevajući da je do isteka toga roka cijena plaćena.

Ovim ovih rješenja, koja bi se moglo opisati kao recipročna, postoje i dodatna rješenja s obzirom na različitu prirodu prodavateljevih i kupčevih obveza i njihov pravni i faktični položaj. Kako prodavatelj može ispuniti svoje obveze nakon njihova dospijeća i sam odrediti rok u kojem će to učiniti, a kupac ima pravo odbiti takvo ispunjenje, ${ }^{84}$ kupac gubi pravo jednostrano raskinuti ugovor zbog druge povrede i u razumnom roku nakon proteka dodatnog roka što ga je odredio sam prodavatelj ili nakon što je sam izjavio da neće prihvatiti izvršenje. ${ }^{85} \mathrm{~S}$ druge strane, kupac gubi pravo jednostrano raskinuti ugovor ako je primio robu, ali ,je ne može vratiti u bitno

81 Čl. 49. (2) (a) i čl. 64. (2) (a) Konvencije. Imajući u vidu engleski izvornik izraz „prema zakasnjeloj isporuci“ iz čl. 49. (2) (a) trebalo je prevesti „,u odnosu na zakašnjelu isporuku“ ili „s obzirom na zakašnjelu isporuku“", jer engleski izvornik rabi frazu in respect of.

82 Čl. 49. (2) (b) (i) i čl. 64. (2) (b) (i) Konvencije.

83 Čl. 49. (2) (b) (ii) i čl. 64. (2) (b) (ii) Konvencije.

84 Prema čl. 48. (1) Konvencije „... prodavalac može, čak i nakon proteka roka za isporuku, na svoj trošak otkloniti svako neizvršenje svojih obveza“, prema čl. 48. (2) „ako prodavalac zahtijeva od kupca da se izjasni da li prihvaća izvršenje ugovora, a kupac mu ne odgovori u razumnom roku, prodavalac može izvršiti ugovor u roku koji je naveden u njegovu zahtjevu...".

85 Čl. 49. (2) (b) (iii) 
istom stanju u kojem je robu primio" ${ }^{86}$ bez obzira na to radi li se o identitetu robe ili drugim elementima (ne)usklađenosti.

Pod nemogućnosti vraćanja treba podrazumijevati stvarnu i objektivnu prepreku vraćanju, kakvu predstavljaju oštećenje, gubitak, uništenje ili krađa robe, dok ekonomske prepreke ne predstavljaju takvu prepreku, ali ona istovremeno ne postoji i kupac neće izgubiti pravo jednostrano raskinuti ugovor ako mu je nemoguće vratiti je u potpuno istovjetnom stanju, nego samo ako mu je nemoguće vratiti robu u bitno istom stanju, a odlučni kriterij za ocjenu o tome je li roba u bitno istom stanju proizlazi iz odgovora na pitanje može li se od prodavatelja razumno očekivati da prihvati vraćenu robu kao ekvivalent onoga što je isporučio. ${ }^{87}$

Nemogućnost vraćanja u istom stanju, koja podrazumijeva i obuhvaća i potpunu nemogućnost vraćanja, međutim, može biti posljedica više razloga za koje kupac ne odgovara. Iako citirano pravilo to ne pokazuje, nego to pokazuju odredbe koje navode iznimke od tog pravila, ono kupcu oduzima pravo na jednostrani raskid ugovora $\mathrm{u}$ svim situacijama u kojima je za navedene nemogućnosti odgovoran kupac, odnosno ono je „dizajnirano kako bi penaliziralo kupca uz čiju odgovornost je stanje robe pogoršano“" ${ }^{88}$ Zbog toga kupac neće izgubiti pravo na jednostrani raskid ugovora ako je roba u cijelosti ili djelomično probala ili oštećena pri pregledu stvari ${ }^{89}$ i ako je nemogućnost vraćanja posljedica događaja za koji kupac ne odgovara. ${ }^{90}$ Osim toga,

86 Čl. 82. st. 1. Konvencije, koji u cijelosti glasi: „Kupac gubi pravo izjaviti da raskida ugovor ili da zahtijeva od prodavaoca da zamijeni robu ako je ne može vratiti u bitno istom stanju u kojem je robu primio".

87 Fountoulakis u Schlechtriem i Schwenzer, Commentary on the UN-Convention on the International Sale of Goods, 1186.

88 Tallon u Bianca i Bonell, Commentary on the International Sales Law, 608. Slično i Jelena Vilus: Komentar Konvencije UN o međunarodnoj prodaji robe, (Zagreb: Informator, 1981.), 178 govori o krivnji kupca, dok Bridge u Kroell, Mistelis i Viscasillas, UN Convention on Contracts for the International Sale of Goods, 1115 smatra da odredba koja održava pravo kupca na jednostrani raskid ugovora kad nemogućnost nije posljedica radnje ili propuštanja kupca, ne govori o odgovornosti kupca, odnosno da se radnju ili propuštanje ne može povezivati s pojmom odgovornosti.

89 Bitno istovjetno prema čl. 417. st. 3. ZOO („Isto vrijedi ako je stvar potpuno ili djelomično propala ili oštećena pri ispunjenju obveze kupca da pregleda stvar, ili ako je kupac prije nego što je otkriven nedostatak potrošio ili izmijenio jedan dio stvari u tijeku njezine redovite uporabe te ako je oštećenje ili izmjena bez značenja.“) i čl. 82. (2) (b) Konvencije (,,ako je roba u cijelosti ili djelomično propala, ili je nastupilo pogoršanje zbog pregleda").

90 Čl. 82. (2) (a) Konvencije (,,ako nemogućnost vraćanja robe ili njezina vraćanja u bitno istom stanju u kojem je primljena nije posljedica radnje ili propusta kupca“). Zaključivanjem $a$ contrario, proizlazi da će kupčevo pravo na jednostrani raskid ugovora biti očuvano kada je nemogućnost posljedica radnje ili propusta bilo koje druge osobe, osim kupca. To, napose, uključuje situacije u kojima je nemogućnost vraćanja posljedica više sile, bilo da je ona nastala prirodnim događajem ili ljudskom radnjom, uključujući i akte vlasti ili prodavateljeve povrede ugovora. U slučaju prodavateljeve bitne povrede ugovora ni slučajnu propast, oštećenje ili gubitak robe nakon prijelaza rizika na kupca ne može se uzeti kao posljedicu radnje ili propusta kupca, jer tada pravila o prijelazu rizika i njegovim posljedicama ne priječe kupca da koristi sredstva koja mu pripadaju u slučaju bitne povrede ugovora. Naime, prema čl. 70. Konvencije „Ako je prodavalac bitno povrijedio ugovor, odredbama čl. 67., 68. i 69. ne sprječava se kupac da se koristi sredstvima koja mu stoje na raspolaganju u slučaju takve povrede“. Ali, kako se 
Konvencija ističe kako kupac neće izgubiti pravo na jednostrani raskid ugovora „ako je roba u cijelosti ili djelomično prodana u redovnom poslovanju ili ju je kupac potrošio ili preradio u toku njezine normalne upotrebe prije nego što je otkrio ili je morao otkriti nedostatak usklađenosti““.91

I u slučaju isporuke robe koja nije slobodna od prava ili potraživanja treće osobe, Konvencija sva kupčeva prava, znači i pravo na jednostrani raskid ugovora, veže uz kupčevu obavijest o pravu ili potraživanju trećega, koju je dužan dostaviti prodavatelju u razumnom roku nakon što je saznao ili morao saznati za postojanje prava ili potraživanja trećega. Ta prava ona veže tako što izostanak ove obavijesti, $\mathrm{i}$ to $\mathrm{u}$ razumnom roku nakon navedenoga trenutka, dovodi do kupčevoga gubitka prava, osim ako je prodavatelj znao za pravo ili potraživanje trećega. ${ }^{92} \mathrm{~S}$ druge strane, pravovremenim obavještavanjem prodavatelja, kupac pridržava prava koja mu pripadaju, ali Konvencija ne sadrži rok čijim istekom bi ona prestala.

\section{ZAKLJUČAK}

Prema ZOO-u jednostrani raskid ugovora jedan je od dva načina na koje ugovor zbog neispunjenja može biti raskinut. Drugi je način vezan za pojam roka kao bitnog sastojka ugovora tako što se u tom slučaju ugovor raskida ipso iure samim istekom tog roka, ako obveza do toga trenutka nije ispunjena.

Različito od toga, Konvencija ne poznaje ni pojam roka kao bitnoga sastojka ugovora, niti raskid ugovora ipso iure, što se opravdano obrazlaže zahtjevom za otklanjanjem neizvjesnosti u pogledu trenutka raskida, pa ugovor može biti raskinut jedino očitovanjem volje savjesne strane i raskinut je kad strana koja je povrijedila ugovor primi takvo očitovanje.

Jednostranim očitovanjem ugovor može biti raskinut zbog neispunjenja $u$ dodatnom roku i zbog bitne povrede ugovora. Raskid zbog neispunjenja u dodatnom roku uređen je na način koji se može usporediti s načinom na koji ga uređuje ZOO, ali istovremeno se i znatno razlikuje $u$ tome što prema Konvenciji ugovor može biti raskinut samo u razumnom roku nakon isteka dodatnog roka za ispunjenje, dok ZOO takvo pravilo ne sadrži. Budući da to rješenje afirmira načelo favor negotii i povećava

to odnosi samo na situacije u kojima je prodavateljeva povreda ugovora bitna, ostaje pitanje gubi li kupac pravo jednostrano raskinuti ugovor kad je rizik prešao na kupca, prodavateljeva povreda ugovora nije bila bitna, a nemogućnost vraćanja je posljedica slučaja. Odgovor na ovo pitanje ovisi o tome je li kupac primijenio potrebnu pozornost pri postupanju s robom, pa gubi pravo jednostrano raskinuti ugovor ako nije, a ne gubi ako je primijenio (Tako Fountoulakis u Schlechtriem i Schwenzer, Commentary on the UN-Convention on the International Sale of Goods, 1190). Na to upućuje i odredba o čuvanju robe koja kupcu nalaže da poduzme sve mjere za očuvanje robe koje su prema okolnostima razumne u situaciji u kojoj je primio robu, a namjerava koristiti pravo da robu odbije (čl. 86. st. 1. Konvencije).

91 Čl. 82. st. 2. Konvencije.

92 Prema čl. 43. (1) Konvencije „kupac gubi pravo koristiti se odredbama članka 41. ili članka 42. ako o pravu ili potraživanju treće osobe ne dostavi prodavaocu obavijest u kojoj je naveo njihovu narav u razumnom roku pošto je saznao ili morao saznati za postojanje takva prava ili potraživanja“, a prema čl. 43. (2) iste Konvencije ,prodavalac nema pravo koristiti se odredbama prethodnog stavka ako je znao za pravo ili potraživanje treće osobe i njihovu narav“. 
pravnu sigurnost, de lege ferenda bi se moglo razmisliti o njegovu prihvaćanju u hrvatskom pravu.

Za razumijevanje koncepta raskida ugovora zbog bitne povrede prvo treba istaći kako Konvencija ne razlikuje neispunjenje predajom druge stvari (aliud) i ispunjenje s materijalnim nedostatcima, nego je oboje obuhvaćeno pojmom usklađenosti robe, tako da i u slučaju isporuke aliud kupac gubi pravo raskinuti ugovor ako o tome nije pravovremeno obavijestio prodavatelja. Konvencija ne rabi ni pojam pravnih nedostataka, nego govori o pravima i potraživanjima trećih osoba, pri čemu prodavatelj ne odgovara samo ako je trećoj osobi zaista pripadalo neko pravo, nego čak i ako neutemeljeno tvrdi da joj ono pripada i time prouzroči štetu kupcu.

Budući da sve te slučajeve Konvencija opisuje izrazom povreda ugovora, u svim je tim slučajevima jednostrani raskid ugovora moguć ako je povreda bitna. Pojam bitne povrede ugovora, iako jezično potječe iz common lawa, posljedica je nastojanja za ,pomirenjem“ različitih pristupa raskidu ugovora u common lawu i zemljama koje slijede tradiciju rimskoga privatnog prava, autonoman je i tako ga treba tumačiti, iako je to neobično teško s obzirom na njegovu definiciju. Iz nje, naime, proizlazi da je povreda ugovora bitna ako drugoj strani bitno oduzme ono što je ona ovlaštena očekivati prema ugovoru, što se općenito uzima kao stanje u kojem su svrha i ekonomski cilj ugovora za savjesnu stranu toliko ugroženi da za ispunjenje više nema interesa, odnosno da ne bi sklopila ugovor da je znala za takvu povredu.

Kako katkad takvo stanje može nastati čim roba nije isporučena na vrijeme može se zaključiti da pojam bitne povrede ugovora obuhvaća slučajeve koje ZOO opisuje kao rok koji je bitan sastojak ugovora. No, dok bi prema ZOO-u ugovor bio raskinut ipso iure, prema Konvenciji je i tada nužno očitovanje raskida savjesne strane koje je prispjelo drugoj strani, kao što je već rečeno.

\section{LITERATURA}

\section{Knjige i članci:}

1. Bianca, Cesare Massimo i Michael Joachim Bonell, eds. Commentary on the International Sales Law the 1980 Vienna Sales Convention. Milan: Giuffrè, 1987.

2. Brnabić, Ratko. Raskid ugovora prema Konvenciji Ujedinjenih naroda o ugovorima o međunarodnoj prodaji robe (Bečka konvencija): magistarski rad. Zagreb: Sveučilište u Zagrebu, Pravni fakultet, 2004.

3. Garner, Bryan A. ed. Black's Law dictionary. 8. izd. St. Paul, MN: West, 2004.

4. Kay, Mairé Weir. Webster's collegiate thesaurus. Springfield, Mass: Merriam-Webster. 1976.

5. Klarić, Petar i Martin Vedriš. Građansko pravo. 8. izd. Zagreb: Narodne novine, 2006.

6. Kröll, Stefan, Loukas Mistelis i Pilar Perales Viscasillas. UN Convention on Contracts for the International Sale of Goods. München: Verlag C.H. Beck, 2011.

7. Magnus, Ulrich. The remedy of avoidance of contract under CISG-General remarks and special cases. Pristup 10. prosinca 2019. https://www.uncitral.org/pdf/english/CISG25/ Magnus.pdf

8. Schlechtriem, Peter i Ingeborg Schwenzer, eds. Commentary on the UN-Convention on the International Sale of Goods (CISG). 2. izd. Oxford: Oxford University Press, 2005.

9. Schlechtriem, Peter i Petra Butler. UN Law on International Sales - The UN Convention on the International Sale of Goods. Berlin: Springer, 2009. 
10. Slakoper, Zvonimir i Vilim Gorenc. Obvezno pravo - opći dio. Zagreb: Novi informator, 2009.

11. Tepeš, Nina i Stjepan Šutija. „Bitna povreda ugovora i pravo prodavatelja na otklanjanje neispunjenja u naknadnom roku prema Konvenciji UN-a o ugovorima o međunarodnoj prodaji robe“, Pravo i porezi 20 (2011.), br. 5: 14-23.

12. Tucak, Ivana. „Pravni odnosi in rem i pravni odnosi in personam“. Pravni vjesnik 27, 2 (2011.): 7-22.

13. Vilus, Jelena. Komentar Konvencije UN o međunarodnoj prodaji robe. Zagreb: Informator, 1981.

Pravni izvori:

1. Konvencija UN o međunarodnoj prodaji robe (Bečka konvencija) Službeni list SFRJ, Međunarodni ugovori br. 10/84. i Narodne novine, Međunarodni ugovori, br. 15/98.

2. Zakon o obveznim odnosima, Narodne novine, br. 35/05., 41/08., 78/15. i 29/18.

Sudska praksa:

1. Odluka Audiencia Provincial Madrid od 20. veljače 2007., odluka br. 1637.

2. Odluka austrijskog Oberste Gerichtshof od 21. lipnja 2005., odluka br. 1047.

3. Odluka austrijskog Oberste Gerichtshof od 5. srpnja 2000., odluka br. 652

4. Odluka Corte d'Appello Milano od 20. ožujka 1998., odluka br. 348.

5. Odluka Handelsgericht Aargau od 5. studeni 2002., odluka br. 715

6. Odluka Međunarodnog arbitražnog sudišta ICC 8128/1995, odluka br. 526.

7. Odluka njemačkog Bundesgerichtshof od 24. rujna 2014., odluka br. 2545.

8. Odluka njemačkog Bundesgerichtshof od 3. travnja 1996., odluka br. 135.

9. Odluka Oberlandesgericht Duesseldorf od 17. studenog 1983.

10. Odluka Oberlandesgericht Frankfurt od 17. rujna 1991., odluka br. 28.

11. Odluka Oberlandesgericht Koeln od 24. travnja 2013., odluka br. 2480.

12. Odluka švicarskog Bundesgericht od 15. rujna 2000, odluka br. 770.

13. Odluka švicarskog Bundesgericht od 23. rujna 2013. odluka br. 2560

14. Odluka švicarskog Bundesgericht od 23. rujna 2013. odluka br. 2560.

15. Odluka Vrhovnog suda Queenslanda od 17. studenog 2000, odluka br. 587. 


\title{
Zvonimir Slakoper* \\ Josip Dešić**
}

\author{
Summary
}

\section{AVOIDANCE OF CONTRACT OF SALE AFTER MATURITY OF THE OBLIGATIONS OF THE PARTIES UNDER THE UN CONVENTION ON THE INTERNATIONAL SALE OF GOODS}

The paper deals with avoidance of a contract of sale after the maturity of the parties' obligations under the UN Convention on the International Sale of Goods (The Vienna Convention). The Vienna Convention is a multilateral treaty establishing a unified legal regime for cross-border sales of goods, which form the backbone of international trade. The Vienna Convention is therefore considered to be one of the fundamental conventions of international commercial law, that is in force in 93 countries from all legal traditions and levels of economic development, which together represent more than two thirds of the global economy, which has greatly contributed to the harmonization of international trade law and the increase degree of legal certainty in international trade. In an effort to be acceptable to different legal systems, the Vienna Convention has largely deviated from the solutions of national rights and legal circles and created autonomous concepts and solutions. Special creative solutions were foreseen for the avoidance of the contract. The paper specifically analyzes avoidance in case of fundamental breach of contract, avoidance in case of the failure to comply with the additional deadline, avoidance in case of non-compliance, as well as avoidance because of the rights or claims of third parties. Particular attention is paid to complete and partial avoidance and avoidance in successive deliveries.

Keywords: avoidance of contract; UN Convention on international sale of goods; fundamental breach of contract.

* Zvonimir Slakoper, Ph.D., Full Professor, University of Rijeka, Faculty of Law; zvonimir. slakoper@pravri.hr.

** Josip Dešić, mag. iur., Research Assistant, University of Rijeka, Faculty of Law; jdesic@pravri. hr. 
Zusammenfassung

\section{EINSEITIGE AUFHEBUNG DES KAUFVERTRAGS NACH DER FÄLLIGKEIT DER PFLICHTEN LAUT ÜBEREINKOMMENS DER VEREINTEN NATIONEN ÜBER VERTRÄGE ÜBER DEN INTERNATIONALEN WARENKAUF}

In diesem Beitrag stellt man einseitige Aufhebung des Kaufvertrags nach der Fälligkeit der Pflichte der Parteien laut Übereinkommens der Vereinten Nationen über Verträge über den internationalen Warenkauf (die Wiener Konvention) dar. Die Wiener Konvention ist heute in 93 Staaten aus allen Rechtstraditionen in Kraft, wobei wirtschaftlicher Entwicklung nach diese Staaten auf unterschiedlichen Ebenen stehen, aber gleichzeitig zwei Drittel globaler Wirtschaft besetzen. Verträge über den grenzüberschreitenden Warenkauf sind das Grüngerüst des internationalen Handels, weshalb die Wiener Konvention als eine der Grundkonventionen des internationalen Handelsrechts gilt. In der Bestrebung, unterschiedlichen Rechtsordnungen akzeptabel zu sein, ist die Wiener Konvention bedeutend von Lösungen der Nationalrechte und Rechtskreise abgewichen und autonome Begriffe und Lösungen geschaffen. Besonders kreative Lösungen hat sie für Vertragsaufhebung vorgesehen. Im Beitrag analysiert man Vertragsaufhebung wegen wesentlicher Vertragsverletzung, was in keinem Ziviloder Handelsgesetz vorgesehen wird. Ebenfalls analysiert man Vertragsaufhebung wegen Nichterfüllung innerhalb der Nachfrist, Vertragsaufhebung wegen NichtEntsprechung sowie Vertragsaufhebung wegen der Rechte oder Ansprüche Dritter. Besonderen Wert legt man auch auf gesamte und teilweise Vertragsaufhebung und auf Vertragsaufhebung bei aufeinander folgenden Lieferungen. Abschließend analysiert man den Verlust des Aufhebungsrechts.

Schlüsselwörter: einseitige Vertragsaufhebung; das UN-Übereinkommen über den internationalen Warenkauf; wesentliche Vertragsverletzung. 
Riassunto

\section{LA RISOLUZIONE DAL COTRATTO DI COMPRAVENDITA DOPO LA SCADENZA DELLE OBBLIGAZIONI DELLE PARTI SECONDO LA CONVENZIONE SULLA VENDITA INTERNAZIONALE DI BENI}

Nel lavoro si illustra risoluzione dal contratto dopo la scadenza delle obbligazioni delle parti secondo la Convenzione sulla vendita internazionale di beni (Convenzione di Vienna). La Convenzione di Vienna oggi è in vigore in 93 stati appartenenti a tutte le tradizioni giuridiche ed a tutti i livelli di sviluppo economico, i quali assieme rappresentano due terzi dell'economia globale. I contratti sulla vendita di beni transfrontaliera costituiscono uno dei pilastri del commercio internazionale. Pertanto, la Convenzione di Vienna si considera una delle convenzioni fondamentali del diritto commerciale internazionale. Nel tentativo di essere condivisibile tra i diversi ordinamenti giuridici, la Convenzione di Vienna in molte soluzioni si è discostata dai diritti nazionali e dagli ambienti giuridici, creando nozioni e soluzioni autonome. Soluzioni particolarmente creative sono state previste in tema di risoluzione. Nel lavoro si analizza la risoluzione causata dalla violazione sostanziale del contratto, un concetto non previsto in nemmeno una legge civile o commerciale; ancora la risoluzione per l'inadempimento nel termine supplementare, la risoluzione per i vizi, come anche la risoluzione per il diritto oppure per la pretesa vantata da una persona terza. Speciale attenzione si dedica alla risoluzione totale o parziale ed alla risoluzione del contratto nelle consegne scaglionate. Infine si analizza la perdita del diritto alla risoluzione.

Parole chiave: risoluzione del contratto di compravendita; Convenzione sulla vendita internazionale di beni; inadempimento serio del contratto. 
